\title{
Sodium Butyrate Combined with Docetaxel for the Treatment of Lung Adenocarcinoma A549 Cells by Targeting Gli I
}

This article was published in the following Dove Press journal: OncoTargets and Therapy

\author{
Maojian Chen ${ }^{1, *}$ \\ Wei Jiang ${ }^{2} *$ \\ Chanchan Xiao ${ }^{3}$ \\ Weiping Yang ${ }^{4}$ \\ Qinghong Qin' \\ Anyun Mao' \\ Qixing Tan' \\ Bin Lian' \\ Changyuan Wei' \\ 'Department of Breast Surgery, Guangxi \\ Medical University Cancer Hospital, \\ Nanning, Guangxi 53002I, People's \\ Republic of China; ${ }^{2}$ Department of \\ Medical Oncology, Guangxi Medical \\ University Cancer Hospital, Nanning, \\ Guangxi 53002I, People's Republic of \\ China; ${ }^{3}$ Department of Microbiology and \\ Immunology, School of Medicine, Jinan \\ University, Guangzhou, Guangdong \\ 510632, People's Republic of China; \\ ${ }^{4}$ Department of Ultrasound Diagnosis, \\ Guangxi Medical University Cancer \\ Hospital, Nanning, Guangxi 53002I, \\ People's Republic of China \\ *These authors contributed equally to \\ this work
}

Correspondence: Changyuan Wei Department of Breast Surgery, Guangxi Medical University Cancer Hospital, Nanning, Guangxi 53002I,

People's Republic of China

$\mathrm{Tel} / \mathrm{Fax}+86$ 77I 5308593

Email changyuanwei@gxmu.edu.cn
Purpose: This study is aimed to investigate the combined treating efficacy of sodium butyrate and docetaxel on proliferation and apoptosis of the lung adenocarcinoma A549 cell line based on Gli1 regulation in vitro and in vivo.

Materials and Methods: RNA interference method was used to overexpress Gli1 in A549 cells. Cells were treated with varying concentrations of sodium butyrate, docetaxel or both in combination. CCK-8, colony formation assay, Hoechst 33258 staining, flow cytometry and TUNEL assay were employed to detect proliferation, cell cycle and apoptosis. qRT-PCR and Western blot analysis were applied to detect the mRNA and protein expression of Gli1. In vivo tumorigenicity was detected by tumor transplantation in nude mice. Downstream protein levels of Gli1 were detected using Western blot assay.

Results: It was found that sodium butyrate or docetaxel alone, respectively, inhibited proliferation and promoted apoptosis of A549 cells in vitro and in vivo, while the combination of the two generated significantly higher responses, which were also effective in another lung adenocarcinoma cell line H1299. Furthermore, the combined therapy had an additive effect in suppressing Gli1 expression and regulating the expression of its downstream proteins that involve in proliferation, cell cycle and apoptosis of A549 cells in vitro and in vivo, including decreased protein expression of Ki-67, CDK1, CDK2, Cyclin D1, Bcl-2 and Survivin, and increased protein expression of Cyclin A, p21, Bax and cleaved-Caspase 3. On the other hand, Gli1 overexpression perceptibly reversed the above-mentioned additive effect in vitro and in vivo.

Conclusion: This study demonstrates that the combined therapy of sodium butyrate and docetaxel additively inhibits proliferation and promotes apoptosis of A549 lung adenocarcinoma cells via suppressing Glil expression in vitro and in vivo. Targeting Glil by the combined therapy may provide new insights into the therapeutic management of patients with lung adenocarcinoma.

Keywords: sodium butyrate, docetaxel, lung adenocarcinoma, A549, Gli1

\section{Introduction}

Lung cancer is the most common malignancy and the leading cause of cancerrelated death. ${ }^{1,2}$ Compared to the other histological types of non-small cell lung cancer (NSCLC), the proportion of lung adenocarcinoma has dramatically increased, reaching $60 \%$ recently. ${ }^{3}$ Unfortunately, approximately $70 \%$ of NSCLC are diagnosed at late and advanced stage. ${ }^{1,4}$ For this population, systemic chemotherapy is one of the essential and standard treatment strategies. ${ }^{5}$ The standard cytotoxic chemotherapy regimens represented by docetaxel in combination with 
platinum in NSCLC first-line therapy have demonstrated appreciably efficacy. However, the treatment outcome of advanced NSCLC remains sub-optimal. Owing to the adverse effects of chemotherapy agents, it is merely impossible to improve the therapeutic efficacy by simply increasing the dosage. Therefore, the combination of an effective and low-toxic agent to chemotherapeutic agents becomes a feasible method to further improve the treatment efficacy.

Sodium butyrate (SB) is a histone deacetylase (HDAC) inhibitor that has been shown to inhibit proliferation, promote apoptosis, and delay invasion as well as metastasis of tumor cells in a variety of cancers, including hepatocellular carcinoma, ${ }^{6}$ breast cancer, ${ }^{7}$ gastric cancer, ${ }^{8}$ bladder cancer, ${ }^{9}$ colorectal cancer, ${ }^{10}$ chronic myeloid leukemia, ${ }^{11}$ lung cancer, ${ }^{12}$ etc. Recently, Xiao and co-workers reported that Sodium butyrate-activated TNF receptor-associated factor 6 (TRAF6)-thioredoxin-interacting protein (TXNIP) pathway affects lung adenocarcinoma cell line A549 proliferation and migration, ${ }^{12}$ suggesting that sodium butyrate has an effective therapeutic effect on lung adenocarcinoma. As a simple molecular structure agent notably produced in large amounts from the dietary fiber in the gut, sodium butyrate combined with chemotherapy agent docetaxel (DTX) may generate additive anti-tumor effect that could possibly improve therapeutic efficacy, which deserves further investigation.

As an essential component in hedgehog (Hh) signaling pathway to regulate gene transcription, ${ }^{13}$ gliomaassociated oncogene homolog 1 (Gli1) is able to facilitate non-classical activation of Hh pathway based on epigenetic gene regulation independent of $\mathrm{Hh}$ ligands. ${ }^{14}$ For example, HDAC-regulated Gli1 deacetylation facilitates transcriptional activity of Gli1 to activate Hh signaling pathway. In turn, the activation of Hh signaling pathway can induce HDAC1 expression, thereby forming a positive feedback loop to stimulate cancer progression persistently. ${ }^{14}$ Previous studies have shown that the overexpression of Gli1 in lung adenocarcinoma leads to activation of the Hh signaling pathway, which finally promotes cancer progression. ${ }^{15,16}$ Therefore, we hypothesized that the administration of HDAC inhibitor-sodium butyrate in lung adenocarcinoma may modulate the transcriptional activity of Glil and inhibit the activation of Hh signaling pathway, which may ultimately inhibit cancer progression. This study is aimed to investigate the combined treating efficacy of sodium butyrate with docetaxel on proliferation and apoptosis of the lung adenocarcinoma cell line A549 based on Gli1 regulation in vitro and in vivo.

\section{Materials and Methods}

\section{Reagents and Antibodies}

Sodium butyrate (Purity $\geq 98 \%$ ) was purchased from Sigma Chemical (St. Louis, MO, USA). Docetaxel was purchased from Jiangsu Hengrui Medicine Co., Ltd. (Lianyungang, China). Cell counting kit-8 was purchased from Dojindo Laboratories (Kumamoto, Japan). Hoechst 33258 and TUNEL assay were purchased from Beyotime Biotechnology Co., Ltd. (Shanghai, China). Cell cycle staining kit was purchased from Multi Sciences Biotech Co., Ltd. (Hangzhou, China). Annexin V-APC/7-AAD apoptosis detection kit was purchased from BD Biosciences (San Diego, CA, USA). The primary antibodies against Gli1 and GAPDH were purchased from Abcam (Cambridge, MA, USA). The primary antibodies against Ki-67, CDK1, CDK2, Cyclin A, Cyclin D1, Bcl-2 and Bax were purchased from Wanlei Biotechnology Co., Ltd. (Shenyang, China). The primary antibodies against p21, cleaved-Caspase 3 and Survivin were purchased from Cell Signaling Technology (Danvers, MA, USA).

\section{Cell Culture}

Human lung adenocarcinoma cell line A549 and H1299 were obtained from the Cell Culture Bank of Chinese Academy of Sciences (Shanghai, China) and cultured in Dulbecco's modified Eagle's medium (DMEM; Gibco, USA) supplemented with $10 \%$ fetal bovine serum (FBS; Gibco, USA), $100 \mu \mathrm{g} / \mathrm{mL}$ streptomycin (Hyclone, USA), and $100 \mathrm{U} / \mathrm{mL}$ penicillin (Hyclone, USA) in a humidified incubator with $5 \% \mathrm{CO}_{2}$ at $37^{\circ} \mathrm{C}$.

\section{Cell Transfection}

RNA interference method was used to overexpress Gli1 in A549 cells. The Gli1 overexpression recombinant lentiviral particles and its corresponding negative control vectors were synthesized by Genechem Co., Ltd. (Shanghai, China). A549 cells were inoculated in 6-well plates at a concentration of $5 \times 10^{4}$ cells/well for $24 \mathrm{~h}$. After being grown to $50-60 \%$ confluency, according to the manufacturer's instructions, the cells were transfected with recombinant Gli1 overexpression lentiviral particles and its corresponding negative control vectors, respectively. The successfully transfected cells were, respectively, named as OE-Gli1 group and Vector group for further study. 


\section{Cell Viability Assay}

Cells were seeded in 96-well plates at a concentration of $2 \times 10^{3}$ cells $/ 100 \mu \mathrm{L} /$ well. After $24 \mathrm{~h}$ incubation, the cells were treated with various concentrations of sodium butyrate $(0 \mathrm{mmol} / \mathrm{L}, 1.25 \mathrm{mmol} / \mathrm{L}, 2.5 \mathrm{mmol} / \mathrm{L}, 5 \mathrm{mmol} / \mathrm{L}, 10$ $\mathrm{mmol} / \mathrm{L}, 20 \mathrm{mmol} / \mathrm{L}$ and $40 \mathrm{mmol} / \mathrm{L})$ or docetaxel $(0 \mathrm{ng} /$ $\mathrm{mL}, 12.5 \mathrm{ng} / \mathrm{mL}, 25 \mathrm{ng} / \mathrm{mL}, 50 \mathrm{ng} / \mathrm{mL}, 100 \mathrm{ng} / \mathrm{mL}, 200$ $\mathrm{ng} / \mathrm{mL}$ and $400 \mathrm{ng} / \mathrm{mL}$ ), respectively. With concentrations determined by prior procedures, sodium butyrate (10 $\mathrm{mmol} / \mathrm{L})$ and docetaxel $(100 \mathrm{ng} / \mathrm{mL})$ were as individual or combined treatment to the cells. With specified treatment duration ( $24 \mathrm{~h}, 48 \mathrm{~h}$ and $72 \mathrm{~h}$ ), each well was added $10 \mu \mathrm{L} \mathrm{CCK}-8$ solution. Incubated for $2 \mathrm{~h}$, the absorbance at $450 \mathrm{~nm}$ was measured by enzyme immunoassay instrument.

\section{Colony Formation Assay}

Cells were inoculated in 6-well plates at a concentration of 500 cells/well. After $24 \mathrm{~h}$ incubation, the cells were treated with setting concentrations determining by cell viability assay of sodium butyrate $(0 \mathrm{mmol} / \mathrm{L}$, $5 \mathrm{mmol} / \mathrm{L}, 10 \mathrm{mmol} / \mathrm{L}$ and $20 \mathrm{mmol} / \mathrm{L})$ or docetaxel $(0$ $\mathrm{ng} / \mathrm{mL}, 50 \mathrm{ng} / \mathrm{mL}, 100 \mathrm{ng} / \mathrm{mL}$ and $200 \mathrm{ng} / \mathrm{mL}$ ), respectively. A comparison between single or combined treatment of sodium butyrate $(10 \mathrm{mmol} / \mathrm{L})$ with docetaxel $(100 \mathrm{ng} / \mathrm{mL})$ was also performed. Cells were treated for $12 \mathrm{~h}$ and then cultured in the normal condition for 14 days. Cells were fixed with $4 \%$ paraformaldehyde solution and stained with $0.1 \%$ crystal violet. The colonies with more than 50 cells were counted. The colony formation rate (Colony formation rate $=$ Number of colonies/Number of inoculated cells $\times 100 \%$ ) ${ }^{17}$ was calculated.

\section{Morphological Observation}

Cells were inoculated in 6-well plates at a concentration of $2 \times 10^{5}$ cells/well for $24 \mathrm{~h}$. Then, the cells were given the same concentrations as colony formation assay of single or combined sodium butyrate and docetaxel treatment. After $48 \mathrm{~h}$, morphological changes were observed using an inverted microscope (Olympus, Tokyo, Japan).

\section{Hoechst 33258 Staining}

After morphological observation, the cells of each group above were fixed with $4 \%$ paraformaldehyde solution and stained with Hoechst 33258. Apoptotic morphological features were observed using a fluorescence microscope (Olympus, Tokyo, Japan).

\section{Flow Cytometric Analysis for Apoptosis}

Cells were inoculated in 6-well plates at a concentration of $2 \times 10^{5}$ cells/well for $24 \mathrm{~h}$. Then, the cells were treated with individual or combined treatment of sodium butyrate (10 $\mathrm{mmol} / \mathrm{L})$ with docetaxel $(100 \mathrm{ng} / \mathrm{mL})$. After incubation for $48 \mathrm{~h}$, treated cells were collected and resuspended in the binding buffer at a concentration of $5 \times 10^{5}$ cells $/ \mathrm{mL}$. Adding $5 \mu \mathrm{L}$ Annexin $\mathrm{V}$-APC and $5 \mu \mathrm{L}$ 7-AAD, the cells were incubated at room temperature in the dark for $15 \mathrm{~min}$ and apoptosis analysis was conducted using a flow cytometer (BD Biosciences, San Jose, CA, USA).

\section{Flow Cytometric Analysis for Cell Cycle}

Cells were inoculated in 6-well plates at a concentration of $2 \times 10^{5}$ cells/well for $24 \mathrm{~h}$. Then, the cells were treated with individual or combined treatment of sodium butyrate (10 $\mathrm{mmol} / \mathrm{L})$ with docetaxel $(100 \mathrm{ng} / \mathrm{mL})$. After incubation for $48 \mathrm{~h}$, treated cells were collected and fixed with $75 \%$ ethanol $\left(-20^{\circ} \mathrm{C}\right.$ pre-cooled) and stored at $4^{\circ} \mathrm{C}$ overnight. After washing three times with PBS, cells were resuspended in the DNA staining solution at a concentration of $5 \times 10^{5}$ cells/ $\mathrm{mL}$ and incubated in darkness at room temperature for 30 min. Thereafter, cell cycle distribution was determined using a flow cytometer (BD Biosciences, San Jose, CA, USA).

\section{Quantitative Real-Time PCR}

Total RNA was extracted with Trizol reagent (Invitrogen, California, USA) according to the manufacturer's instructions. Then, cDNA was generated using a Reverse Transcriptase kit (Takara, Kusatsu, Japan). Then, the cDNA was used as template to determine the level of mRNA expression. The specific primers for Gli1 and GAPDH were as follows: Gli1 5'GGAAGTCATACTCACGCCTCGA-3' (Forward), 5'-CATT GCTGAAGGCTTTACTGCA-3' (Reverse); GAPDH 5'-AG AAGGCTGGGGCTCATTTG-3' (Forward), 5'-AGGGGC CATCCACAGTCTTC-3' (Reverse). The quantitative realtime PCR (qRT-PCR) reactions were carried out in a Mx3000P System (Agilent Technologies, CA, USA) using a SYBR Premix Ex TaqTM II real-time PCR kit (Takara, Kusatsu, Japan). Each reaction was assessed in triplicate, and GAPDH was regarded as the internal control to normalize the results.

\section{Western Blot Analysis}

The harvested cells or the fresh xenograft tumor tissues were lysed with ice-cold RIPA lysis buffer (Solarbio, Beijing, China) containing a protease inhibitor cocktail (Solarbio, 
Beijing, China) to obtain the total protein. The bicinchoninic acid method was conducted to measure the concentration of the total protein. An aliquot of protein was separated by sodium dodecyl sulfate-polyacrylamide gel electrophoresis (SDS-PAGE) and transferred onto polyvinylidene difluoride (PVDF) membranes (Solarbio, Beijing, China). Blocked with $5 \%$ non-fat milk for $1 \mathrm{~h}$ at room temperature, the PVDF membranes were incubated overnight at $4^{\circ} \mathrm{C}$ with primary antibodies against Gli1 (1:1000), Ki-67 (1:500), CDK1 (1:1000), CDK2 (1:1500), Cyclin A (1:1000), Cyclin D1 (1:500), p21 (1:1000), Bcl-2 (1:500), Bax (1:500), cleavedCaspase 3 (1:1000), Survivin (1:1000) and GAPDH (1:1000), respectively. Then, the PVDF membranes were incubated with horseradish peroxidase-conjugated secondary antibodies for $1 \mathrm{~h}$. Finally, the expression levels of labeled proteins were assessed using enhanced chemiluminescence system ChemiDoc MP (BioRad, Hercules, CA, USA).

\section{In vivo Xenograft Tumor Model Study}

Female BALB/c nude mice (5 weeks, 16-18 g) were purchased from Guangxi Medical University Experimental Animal Center. All procedures of laboratory animals were approved by the Guangxi Medical University Experimental Animal Committee, and were performed in accordance with the Institutional Animal Welfare Guidelines set by Guangxi Medical University. All nude mice were kept in specific pathogen-free animal house and fed with water and food ad libitum. Twenty nude mice were subcutaneously inoculated with A549 cells (with Gli1 overexpression or negative control vectors) on the fat layer of left front leg at random (ten in each setting). When tumor volume reached around about $100 \mathrm{~mm}^{3}$, two settings of nude mice were further divided into four groups (five in each setting), including: Vector, OEGli1, OE-Gli1+SB+DTX and Vector+SB+DTX. The mice in OE-Gli1+SB+DTX group and Vector+SB+DTX group were intraperitoneally injected with sodium butyrate $(500 \mathrm{mg} / \mathrm{kg}$, once a day) and docetaxel ( $8 \mathrm{mg} / \mathrm{kg}$, once in three days), whereas Vector group and OE-Gli1 group were intraperitoneally injected with an equal volume of phosphate-buffered saline (PBS) at the corresponding time point. The doses of sodium butyrate and docetaxel were set referring to the previous studies. ${ }^{18,19}$ The weight and the tumor size of each mouse during the experiment were measured every three days. The tumor volume was calculated as follows: volume $\left(\mathrm{mm}^{3}\right)=$ length $(\mathrm{mm}) \times$ width $(\mathrm{mm})^{2} / 2$. After 21 days of the first treatment, all mice were euthanized and their tumor nodules were excised, photographed, weighed and harvested.

\section{TUNEL Assay}

Harvested fresh tumor tissues were fixed with $4 \%$ paraformaldehyde, embedded in paraffin and sectioned of $4 \mu \mathrm{m}$ thick. The tissue sections were subsequently deparaffinized, rehydrated, and cooked with citrate buffer ( $\mathrm{pH}$ 6.0) under high pressure for antigen retrieval. Then the tissue sections were stained with TUNEL according to the manufacturer's instructions. After nuclear staining by 4,6-diamidino-2- phenylindole (DAPI). The TUNEL positive cells in 5 random fields exhibiting red fluorescent granules were determined under a fluorescence microscope (Olympus, Tokyo, Japan) and quantified by using Image-Pro Plus 5.0 software (Media Cybernetics, Maryland, MD, USA).

\section{Statistical Analysis}

All data were presented as mean \pm standard deviation (SD). The differences between data were evaluated by Student's $t$-test or one-way ANOVA. All statistical analyses were conducted using the SPSS v17.0 software (SPSS Inc, Chicago, USA). In any case, a $p$ value less than 0.05 was considered statistical significance.

\section{Results}

\section{Sodium Butyrate Inhibits Proliferation and Promotes Apoptosis of A549 Cells}

We first explored the effects of sodium butyrate on proliferation and apoptosis of A549 cells. The CCK-8 assay was conducted and the results showed that sodium butyrate inhibited A549 cell viability at both a dose- and a time-dependent manner (Figure 1A). To confirm these results, we further performed colony formation assay and demonstrated that sodium butyrate elicited a significant inhibition on A549 cell colony-forming ability in a dose-dependent manner (Figure 1B). Additionally, we also examined the morphological changes, as shown in Figure 1C, wherein A549 cells, after treated with sodium butyrate, presented distinct morphological changes, including increased cytoplasmic particles, shrinking, rounded, poor adhesion, shedding and lifeless. The changes became more obvious as the dose of sodium butyrate increased. Subsequently, we performed Hoechst 33258 staining, and the results showed that A549 cells treated with sodium butyrate exhibited higher rate of apoptotic cells with fragmented nuclei and condensed chromatin in a dosedependent manner (Figure 1D). Collectively, these data suggest that sodium butyrate indeed effectively inhibits proliferation and promotes apoptosis of A549 cells. 
A

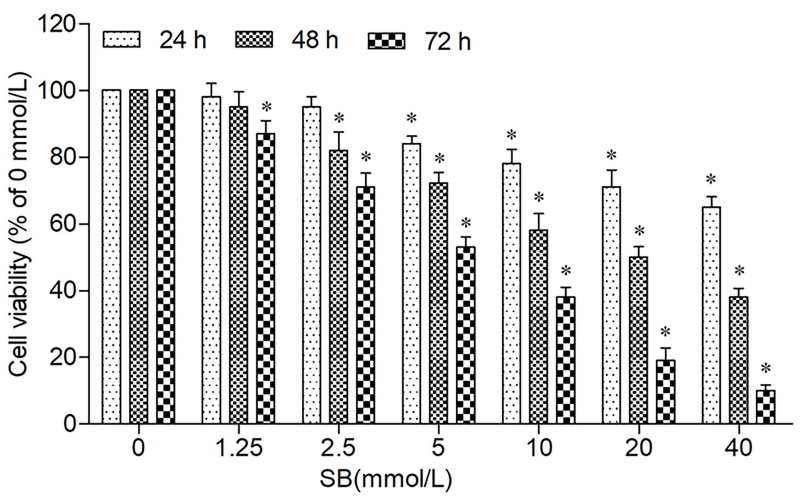

B

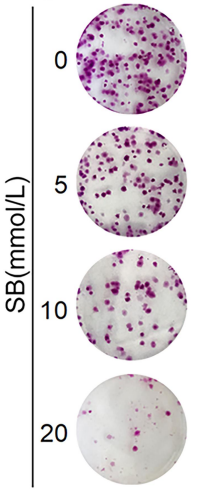

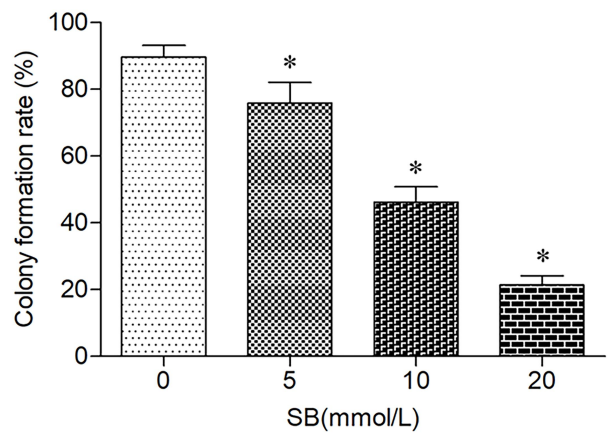

C $\mathrm{SB}(\mathrm{mmol} / \mathrm{L})$
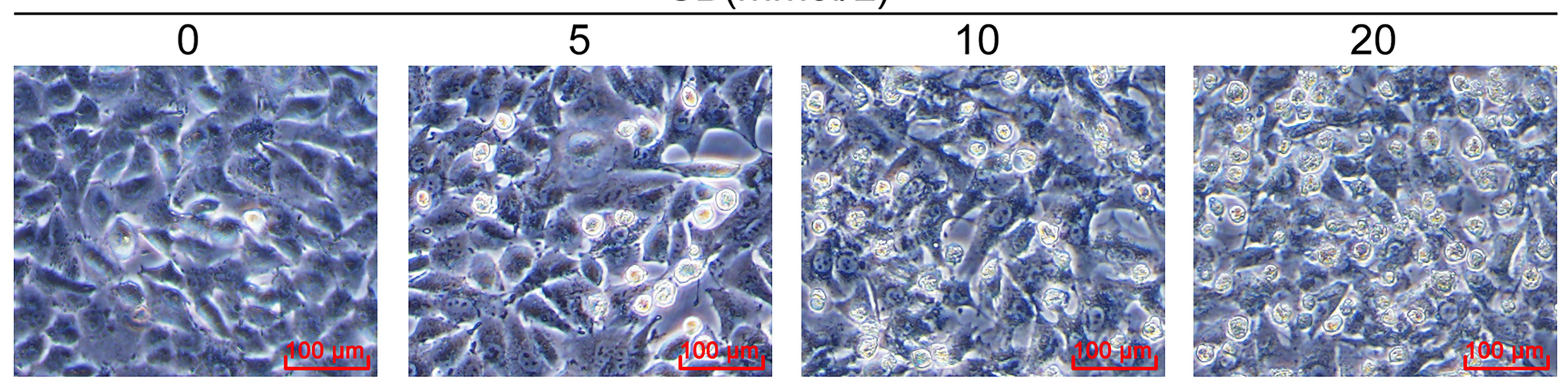

D $\mathrm{SB}(\mathrm{mmol} / \mathrm{L})$
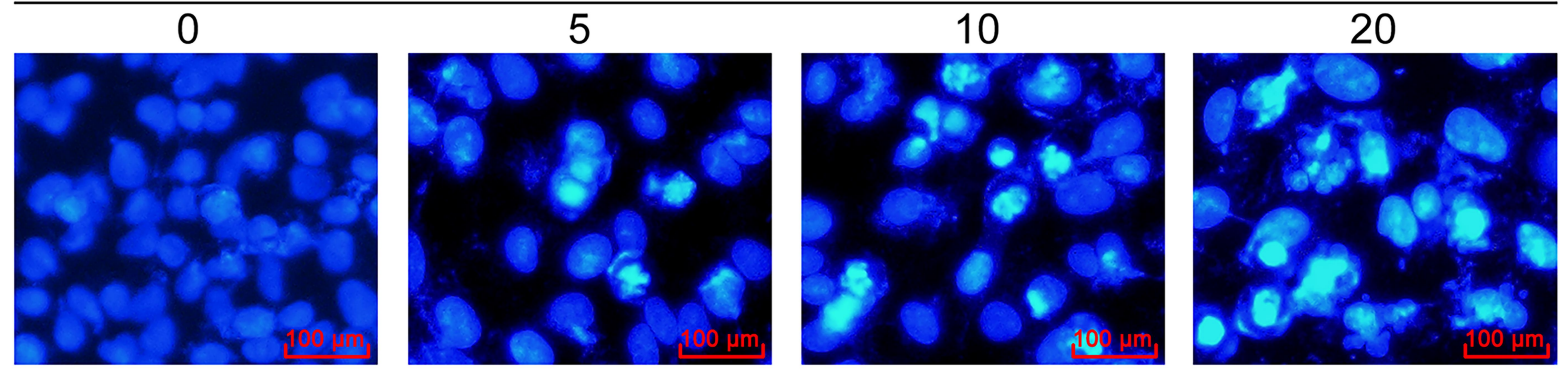

Figure I Sodium butyrate inhibits proliferation and promotes apoptosis of A549 cells. (A) Cells were treated with the indicated concentrations of sodium butyrate for 24 h, $48 \mathrm{~h}$ and $72 \mathrm{~h}$. The cell viability was measured using CCK-8 assay. Data are expressed as mean \pm SD ( $\mathrm{n}=3$ per group), ${ }^{*} p<0.05$ vs Control $(0 \mathrm{mmol} / \mathrm{L})$. (B) Cells were treated with the indicated concentrations of sodium butyrate for $12 \mathrm{~h}$, and then cultured in the normal condition for 14 days. The colony-forming ability was measured using colony formation assay. Data are expressed as mean $\pm S D\left(n=3\right.$ per group), ${ }^{*} p<0.05$ vs Control $(0$ mmol/L). (C) Cells were treated with the indicated concentrations of sodium butyrate for $48 \mathrm{~h}$. The morphological changes were observed using an inverted microscope (scale bar $100 \mu \mathrm{m}$ ). (D) Cells were treated with the indicated concentrations of sodium butyrate for $48 \mathrm{~h}$. The apoptotic morphological features were observed using a fluorescence microscope (scale bar $100 \mu \mathrm{m})$.

\section{Docetaxel Inhibits Proliferation and Promotes Apoptosis of A549 Cells}

In parallel, we also investigated the effects of docetaxel on proliferation and apoptosis of A549 cells. The CCK-8 results showed that docetaxel elicited a significant inhibition on the cell viability in a doseand a time-dependent manner (Figure 2A). The results of colony formation assay verified that docetaxel significantly inhibited the cell colony-forming ability (Figure 2B). The morphological observation showed that docetaxel significantly changed the cell morphology, such as increased cytoplasmic particles, shrinking, rounded, poor adhesion, shedding and lifeless. The changes became more obvious as the dose of docetaxel increased (Figure 2C). Moreover, Hoechst 33258 staining results indicated that docetaxel also induced apoptotic death in a dose-dependent manner (Figure 2D). Taken together, these results suggest that docetaxel is potent to inhibit proliferation and promote apoptosis of A549 cells. 

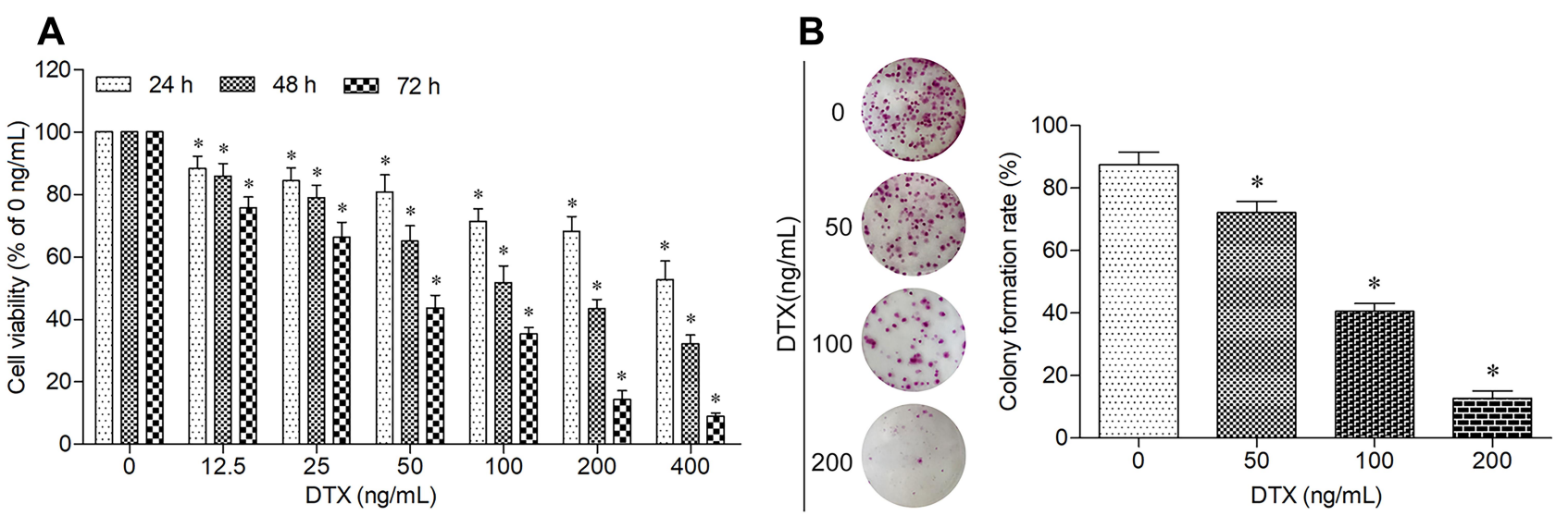

C

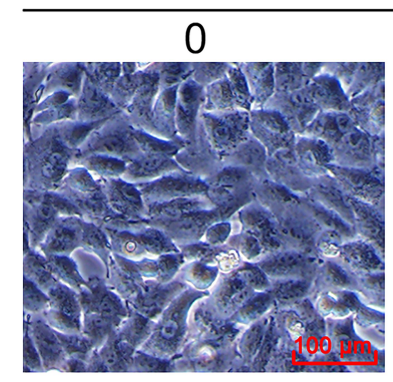

$\mathrm{DTX}(\mathrm{ng} / \mathrm{mL})$
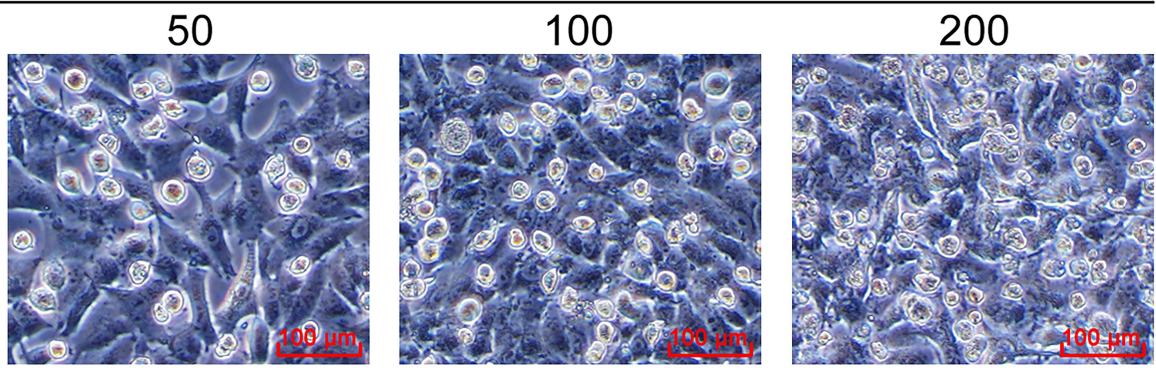

D $\mathrm{DTX}(\mathrm{ng} / \mathrm{mL})$
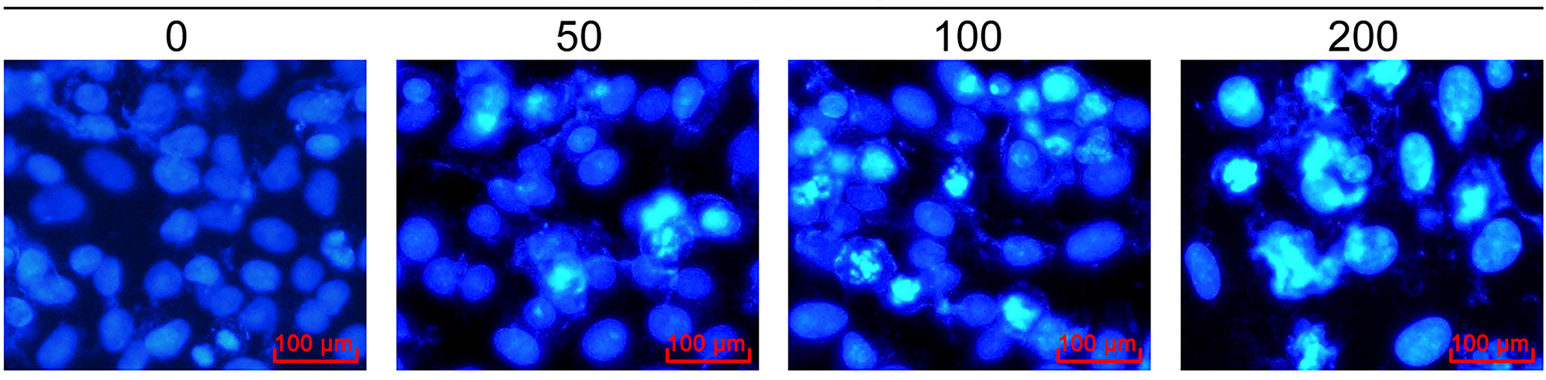

Figure 2 Docetaxel inhibits proliferation and promotes apoptosis of A549 cells. (A) Cells were treated with the indicated concentrations of docetaxel for $24 \mathrm{~h}, 48 \mathrm{~h}$ and 72 h. The cell viability was measured using CCK- 8 assay. Data are expressed as mean \pm SD ( $\mathrm{n}=3$ per group), ${ }^{*} p<0.05$ vs Control $(0 \mathrm{ng} / \mathrm{mL})$. (B) Cells were treated with the indicated concentrations of docetaxel for $12 \mathrm{~h}$, and then cultured in the normal condition for 14 days. The colony-forming ability was measured using colony formation assay. Data are expressed as mean \pm SD ( $n=3$ per group), ${ }^{*} p<0.05$ vs Control $(0 \mathrm{ng} / \mathrm{mL})$. (C) Cells were treated with the indicated concentrations of docetaxel for $48 \mathrm{~h}$. The morphological changes were observed using an inverted microscope (scale bar $100 \mu \mathrm{m}$ ). (D) Cells were treated with the indicated concentrations of docetaxel for $48 \mathrm{~h}$. The apoptotic morphological features were observed using a fluorescence microscope (scale bar $100 \mu \mathrm{m}$ ).

\section{Combined Treatment of Sodium Butyrate} with Docetaxel Exerts a Greater Effect on Proliferation Inhibition, Apoptosis Promotion and Cell Cycle Arrest of A549 Cells

Based on the results of the two drugs investigated above, 10 $\mathrm{mmol} / \mathrm{L}$ sodium butyrate and $100 \mathrm{ng} / \mathrm{mL}$ docetaxel were selected to further study the combined treating efficacy on growth of A549 cells. As expected, the combined therapy of sodium butyrate with docetaxel showed much higher inhibition of cell viability and colony-forming ability as compared to each of the two drugs individually (Figure 3A and B). The morphological observation showed serious changes than either sodium butyrate or docetaxel alone (Figure 3C). Furthermore, the results of both Hoechst 33258 staining and flow cytometric analysis indicated that the combined therapy elicited a remarkable apoptosis induction as compared to either sodium butyrate or docetaxel alone (Figure 3D and E). In addition, the cell cycle analysis from flow cytometry showed that the 

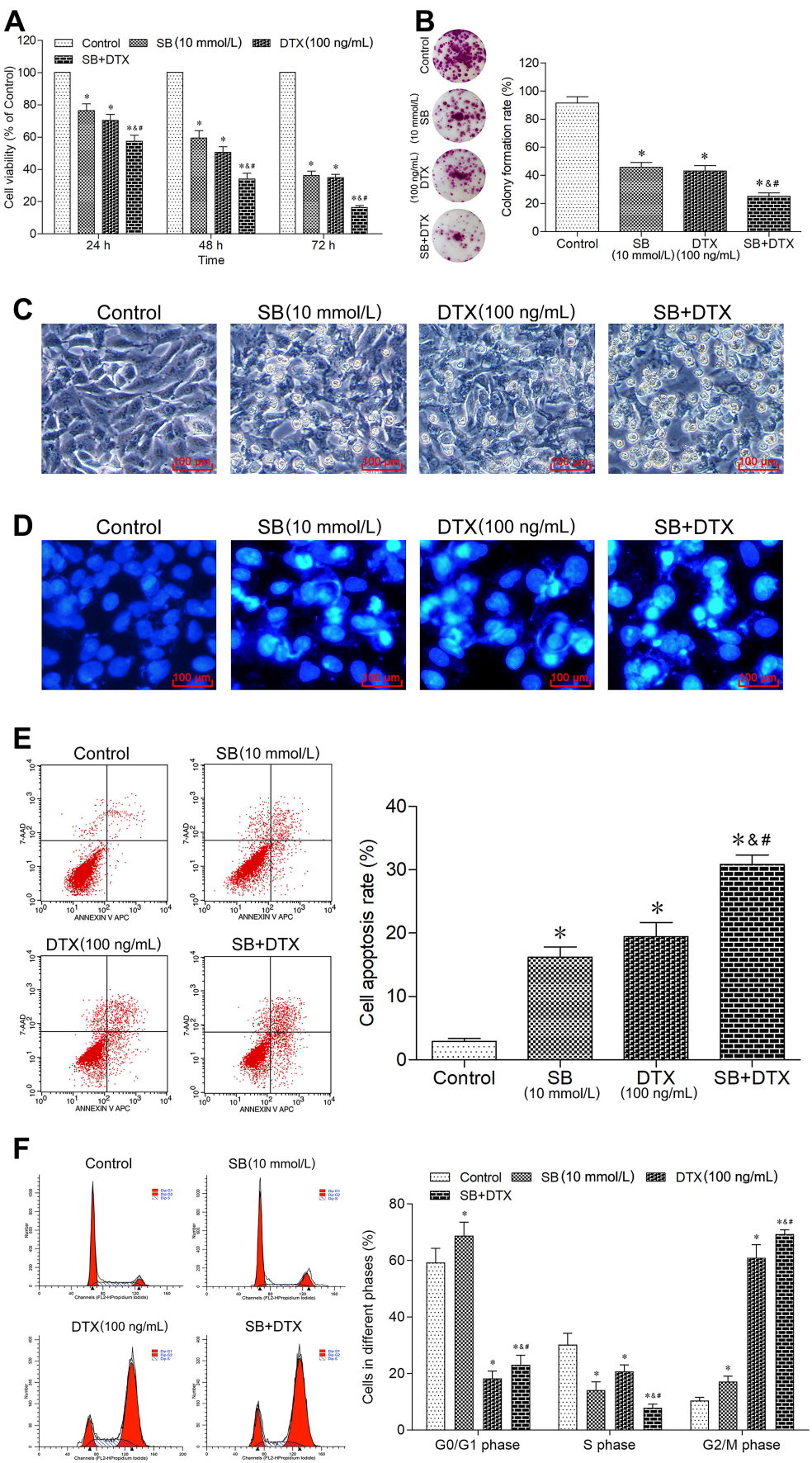

Figure 3 Combined treatment of sodium butyrate with docetaxel additively inhibits proliferation, promotes apoptosis and induces cell cycle arrest of A549 cells. (A) Cells were treated with sodium butyrate $(10 \mathrm{mmol} / \mathrm{L})$ or docetaxel $(100 \mathrm{ng} / \mathrm{mL})$ or a combination of both for $24 \mathrm{~h}, 48 \mathrm{~h}$ and $72 \mathrm{~h}$. The cell viability was measured using CCK-8 assay. Data are expressed as mean \pm SD ( $n=3$ per group), ${ }^{*} p<0.05$ vs Control; ${ }^{*} p<0.05$ vs SB; ${ }^{*} p<0.05$ vs DTX. (B) Cells were treated with sodium butyrate (I0 mmol/L) or docetaxel $(100 \mathrm{ng} / \mathrm{mL})$ or a combination of both for $12 \mathrm{~h}$, and then cultured in the normal condition for 14 days. The colony-forming ability was measured using colony formation assay. Data are expressed as mean \pm SD ( $n=3$ per group), ${ }^{*} p<0.05$ vs Control; ${ }^{\&} p<0.05$ vs SB; ${ }^{*} p<0.05$ vs DTX. (C) Cells were treated with sodium butyrate (I0 $\mathrm{mmol} / \mathrm{L}$ ) or docetaxel $(100 \mathrm{ng} / \mathrm{mL}$ ) or a combination of both for $48 \mathrm{~h}$. The morphological changes were observed using an inverted microscope (scale bar I00 $\mu \mathrm{m}$ ). (D) Cells were treated with sodium butyrate $(10 \mathrm{mmol} / \mathrm{L})$ or docetaxel $(100 \mathrm{ng} / \mathrm{mL})$ or a combination of both for $48 \mathrm{~h}$. The apoptotic morphological features were observed using a fluorescence microscope (scale bar $100 \mu \mathrm{m})$. (E) Cells were treated with sodium butyrate $(10 \mathrm{mmol} / \mathrm{L})$ or docetaxel $(100 \mathrm{ng} / \mathrm{mL})$ or a combination of both for $48 \mathrm{~h}$. The cell apoptosis rate was analyzed using a flow cytometer. Data are expressed as mean \pm SD ( $n=3$ per group), ${ }^{*} p<0.05$ vs Control; ${ }^{\&} p<0.05$ vs SB; ${ }^{*} p<0.05$ vs $D T X$. (F) Cells were treated with sodium butyrate $(10 \mathrm{mmol} / \mathrm{L})$ or docetaxel $(100 \mathrm{ng} / \mathrm{mL})$ or a combination of both for 48 h. The cell cycle distribution was determined using a flow cytometer. Data are expressed as mean \pm SD ( $n=3$ per group), ${ }^{*} p<0.05$ vs Control; ${ }^{\circledR} p<0.05$ vs $S B ;{ }^{\#} p<0.05$ vs DTX. 

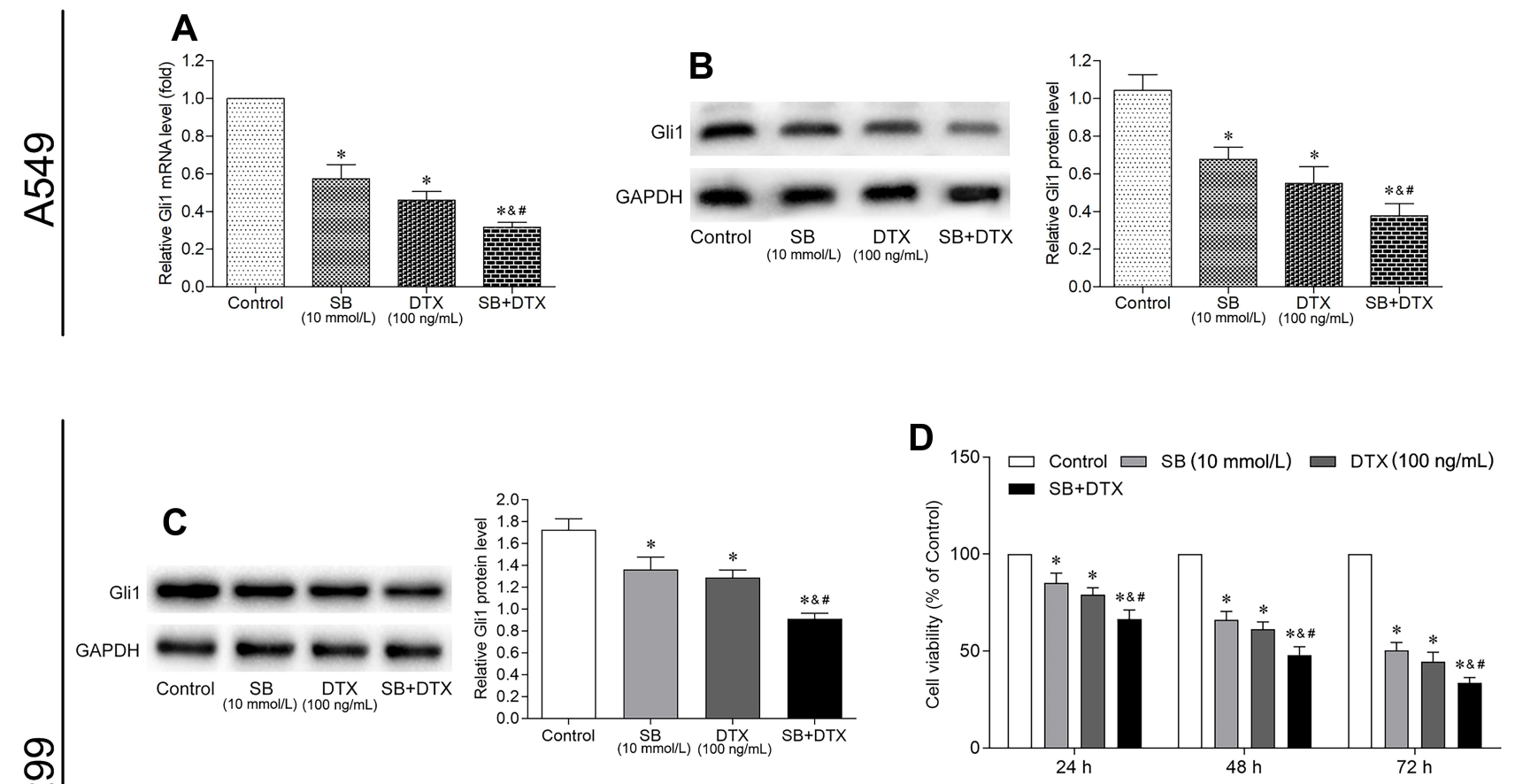

E
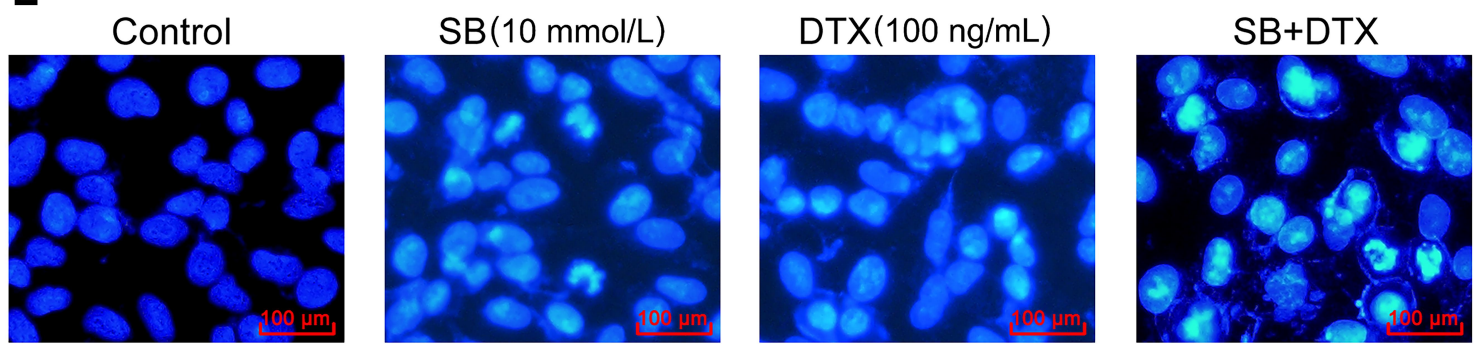

Figure 4 Combined treatment of sodium butyrate with docetaxel additively suppresses Glil expression in A549 cells, and inhibits Glil expression as well as growth in HI299 cells. Cells were treated with sodium butyrate ( $10 \mathrm{mmol} / \mathrm{L})$ or docetaxel $(100 \mathrm{ng} / \mathrm{mL})$ or a combination of both for $48 \mathrm{~h}$, and the mRNA (A) and protein (B and C) expression of Glil were subsequently determined by qRT-PCR and Western blot, respectively. Data are expressed as mean \pm SD ( $\mathrm{n}=3$ per group), $* p<0.05$ vs Control; $\&_{p}<0.05$ vs SB; ${ }^{\#} p<0.05$ vs DTX. (D) Cells were treated with sodium butyrate $(10 \mathrm{mmol} / \mathrm{L})$ or docetaxel $(100 \mathrm{ng} / \mathrm{mL})$ or a combination of both for $24 \mathrm{~h}, 48 \mathrm{~h}$ and $72 \mathrm{~h}$. The cell viability was measured using CCK-8 assay. Data are expressed as mean \pm SD ( $n=3$ per group), ${ }^{*} p<0.05$ vs Control; ${ }^{\circledR} p<0.05$ vs SB; ${ }^{*} p<0.05$ vs $D T X$. (E) Cells were treated with sodium butyrate $(10 \mathrm{mmol} / \mathrm{L})$ or docetaxel $(100 \mathrm{ng} / \mathrm{mL})$ or a combination of both for $48 \mathrm{~h}$. The apoptotic morphological features were observed using a fluorescence microscope (scale bar $100 \mu \mathrm{m})$.

combined therapy significantly decreased percentage of cells blocked in S phase in A549 cells as compared to either sodium butyrate or docetaxel alone, resulting in increased G0/G1 and G2/M-phase arrest (Figure 3F). Altogether, our data suggest that combined treatment of sodium butyrate and docetaxel exhibits additive effect in inhibiting proliferation, promoting apoptosis and inducing cell cycle arrest of A549 cells.

\section{Combined Treatment of Sodium Butyrate with Docetaxel Additively Suppresses Glil Expression in A549 Cells}

With these promising results, we further explored the underlying mechanisms by which sodium butyrate and docetaxel combined treatment inhibit growth in A549 cells. Previous studies have shown that Glil plays an important role in tumorigenesis and progression, ${ }^{15,16}$ and thus we investigated whether the combined treatment could inhibit the expression of Gli1 in our study. In this context, qRT-PCR and Western blot were conducted to detect the mRNA and protein expression of Gli1. As can be seen from parts A and B of Figure 4, the mRNA and protein expression of Gli1 were significantly suppressed with individual or combined treatment of sodium butyrate and docetaxel, with a more remarkable suppression for the combined therapy. These results suggest that combined treatment of sodium butyrate with docetaxel has an additive effect in suppressing Gli1 expression in A549 cells. 
Combined Treatment of Sodium Butyrate with Docetaxel Additively Suppresses Glil Expression and Inhibits Growth in Lung Adenocarcinoma Cell Line HI299

The above results prompted us to examine if such additive effect may also occur in other lung adenocarcinoma cell line. For this purpose, H1299 cells were treated with sodium butyrate $(10 \mathrm{mmol} / \mathrm{L})$ or docetaxel $(100 \mathrm{ng} / \mathrm{mL})$ or a combination of both. Consistently, the results of Western blot showed that the combined treatment could also significantly suppress the expression of Gli1 protein as compared to either sodium butyrate or docetaxel alone (Figure 4C). Moreover, the results of CCK-8 and Hoechst 33258 staining showed that the combined treatment exerted a greater effect on proliferation inhibition and apoptosis promotion when compared with each agent individually (Figure 4D and F). These results suggest that the additive effect of the combined treatment not only occurs specifically in A549 cells, but also in other lung adenocarcinoma cell lines such as H1299.

\section{Glil Overexpression Reverses the Additive Effect of Sodium Butyrate with Docetaxel Combined Treatment on Proliferation Inhibition and Apoptosis Promotion in A549 Cells}

In order to confirm the relationship between the effects of Gli1 and the combined treatment mechanisms of proliferation inhibition, as well as apoptosis promotion in A549 cells, we further investigated whether Glil overexpression could reverse the additive effect. We induced the overexpression of Gli1 via recombinant Gli1 overexpression lentiviral particles transfection. Our transfection experiments indicated the successful Gli1 overexpressing efficiency (Figure 5A-C). Subsequently, the results from CCK-8 and colony formation assay demonstrated that Gli1 overexpression triggered the cell proliferation, and partly abrogated the anti-proliferation effect induced by individual or the combined treatment (Figure 5D and E). The overexpression of Glil ameliorated the serious morphological changes induced by individual or the combined treatment (Figure 5F). Besides, the effect of Gli1 overexpression on apoptosis was detected by Hoechst 33258 staining and flow cytometry, and the results of which demonstrated that Glil overexpression partially abrogated the pro-apoptosis effect induced by individual or the combined treatment (Figure $5 \mathrm{G}$ and $\mathrm{H}$ ). Together, these data suggest that the combined treatment could additively antagonize Gli1 expression during the process of its proliferation inhibition and apoptosis promotion in A549 cells.

\section{Glil Overexpression Reverses the} Additive Effect of Sodium Butyrate with Docetaxel Combined Treatment on Its Downstream Proteins Related to Proliferation, Cell Cycle and Apoptosis in A549 Cells

Encouraged by these results, we further examined the downstream proteins of Glil involving in growth in A549 cells. In line with our expectation, the Western blot results showed that Gli1 overexpression in A549 cells significantly increased the protein expressions of Ki-67, CDK1, CDK2, Cyclin D1, Bcl-2 and Survivin, and decreased the protein levels of Cyclin A, p21, Bax and cleaved-Caspase 3 . We also noted that the individual or the combined treatment significantly decreased the protein expressions of Ki-67, CDK1, CDK2, Cyclin D1, Bcl-2 and Survivin, and significantly increased the protein levels of Cyclin A, p21, Bax and cleaved-Caspase 3. Notably, the effect generated by individual or the combined treatment on the expression levels of the above-mentioned proteins was perceptibly abrogated under Gli1 overexpression (Figure 6). Collectively, these findings suggest that the combined treatment exhibits anti-tumor activity in A549 cells through suppressing the expression of Gli1 and regulating its downstream targets related to proliferation, cell cycle, and apoptosis.

Combined Treatment of Sodium Butyrate with Docetaxel Additively Inhibits in vivo A549 Cell Xenograft Tumor Growth via Suppressing Glil Expression

Finally, to further assess the results obtained from in vitro study, we investigated whether the combined treatment also exhibits anti-tumor effect in vivo. There was neither obvious loss of appetite, nausea/vomiting, nor significant decrease of body weight in the mice throughout the course of experiment (Figure 7A). Furthermore, the combined treatment significantly reduced tumor size and tumor weight. In sharp contrast, Glil overexpression significantly accelerated tumor size and tumor weight. More importantly, the inhibitory effect of tumor growth indices (tumor size and tumor weight) 
A

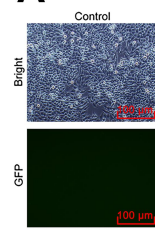

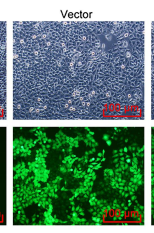
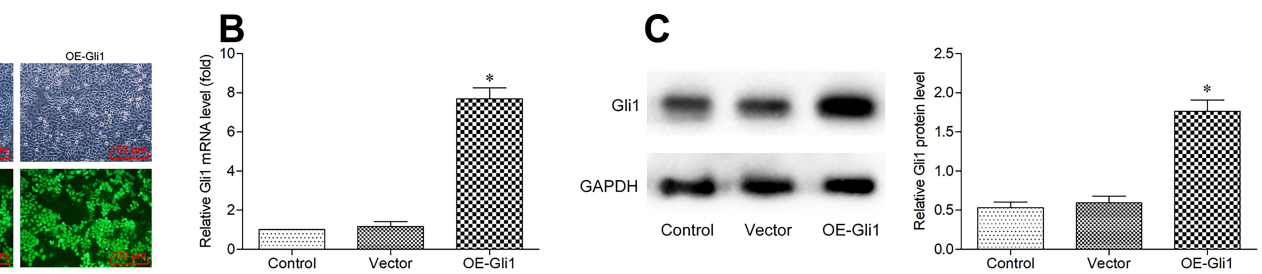

D
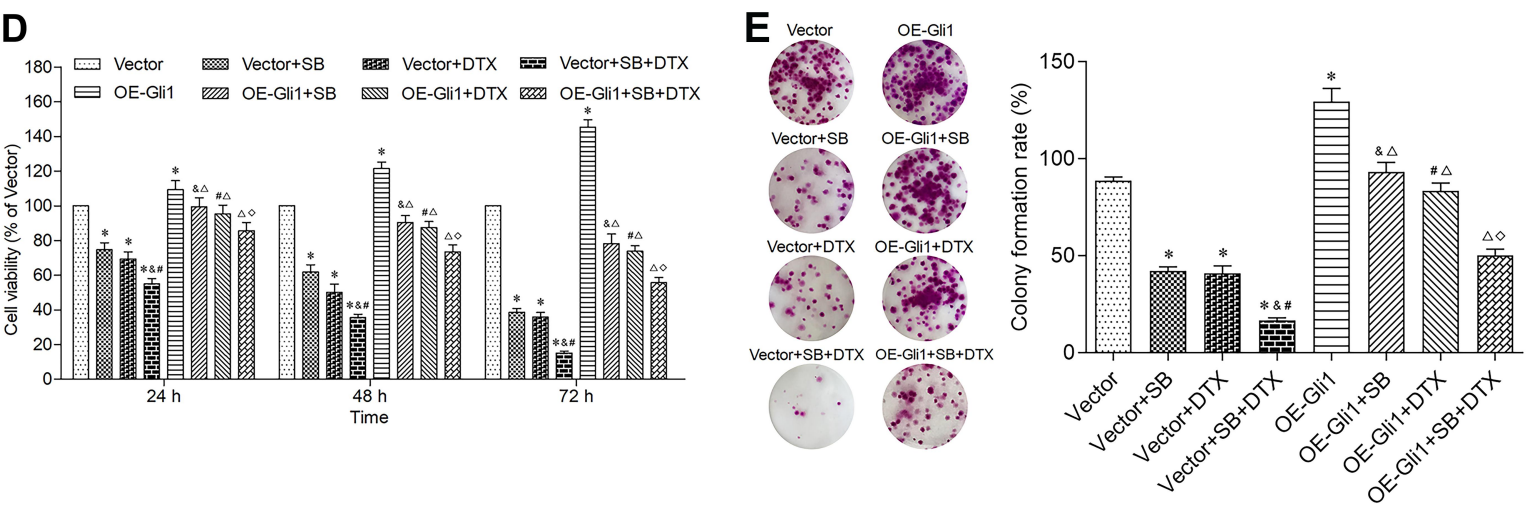
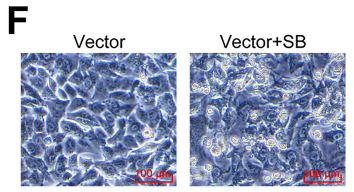

OE-Gli1

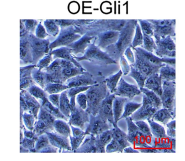

OE-Gli1+S

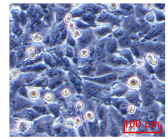

G
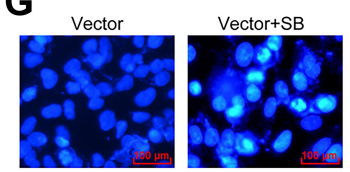

OE-Gli1+SB
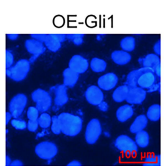

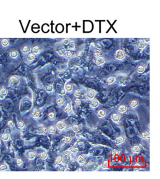

OE-Gli1+DTX
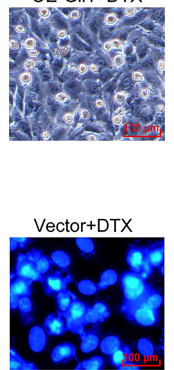

OE-Gli1+DTX

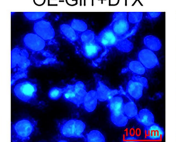

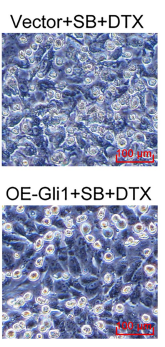

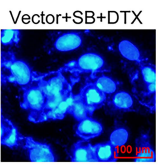

OE-Gli1+SB+DTX

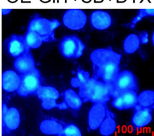

\section{H}
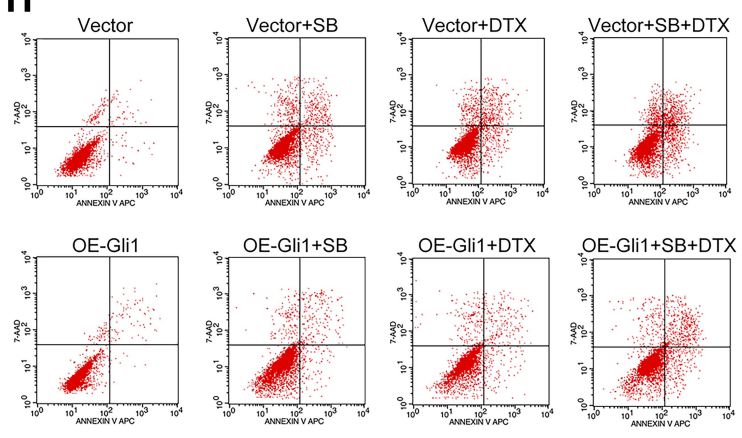

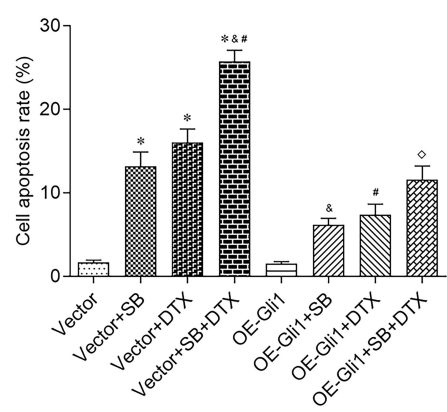

Figure $5 \mathrm{Glil}$ overexpression reverses the additive effect of sodium butyrate with docetaxel combined treatment on proliferation inhibition and apoptosis promotion in A549 cells. (A) Cells were transfected with recombinant Glil overexpression lentiviral particles and its corresponding negative control vectors, respectively. The transfection efficiency was evaluated by an inverted fluorescence microscope (scale bar $100 \mu \mathrm{m}$ ). (B and C) The overexpressing efficiency of Glil was detected by qRTPCR and Western blot, respectively. Data are expressed as mean \pm SD ( $n=3$ per group), ${ }^{*} p<0.05$ vs Vector. (D) After successful transfection of Gli I, cells were treated with sodium butyrate $(10 \mathrm{mmol} / \mathrm{L})$ or docetaxel $(100 \mathrm{ng} / \mathrm{mL})$ or a combination of both for $24 \mathrm{~h}, 48 \mathrm{~h}$ and $72 \mathrm{~h}$. The cell viability was measured using CCK-8 assay. Data are expressed as mean \pm SD ( $n=3$ per group), ${ }^{*} p<0.05$ vs Vector; ${ }^{*} p<0.05$ vs Vector+SB; ${ }^{\#} p<0.05$ vs Vector+DTX; ${ }^{\Delta} p<0.05$ vs OE-Glil; ${ }^{\diamond} p<0.05$ vs Vector+SB+DTX. (E) After successful transfection of Glil, cells were treated with sodium butyrate $(10 \mathrm{mmol} / \mathrm{L})$ or docetaxel $(100 \mathrm{ng} / \mathrm{mL})$ or a combination of both for $12 \mathrm{~h}$, and then cultured in the normal condition for 14 days. The colony-forming ability was measured using colony formation assay. Data are expressed as mean $\pm S D$ ( $n=3$ per group), $* p<0.05$ vs Vector; ${ }_{p}<<0.05$ vs Vector+SB; ${ }_{p} p<0.05$ vs Vector+DTX; ${ }^{\Delta} p<0.05$ vs OE-Glil; ${ }^{\diamond} p<0.05$ vs Vector+SB+DTX. (F) After successful transfection of Glil, cells were treated with sodium butyrate $(10 \mathrm{mmol} / \mathrm{L})$ or docetaxel $(100 \mathrm{ng} / \mathrm{mL})$ or a combination of both for $48 \mathrm{~h}$. The morphological changes were observed using an inverted microscope $(\mathrm{scale}$ bar 100 $\mu \mathrm{m})$. (G) After successful transfection of Glil, cells were treated with sodium butyrate $(10 \mathrm{mmol} / \mathrm{L})$ or docetaxel $(100 \mathrm{ng} / \mathrm{mL})$ or a combination of both for $48 \mathrm{~h}$. The apoptotic morphological features were observed using a fluorescence microscope (scale bar $100 \mu \mathrm{m}$ ). (H) After successful transfection of Glil, cells were treated with sodium butyrate $(10 \mathrm{mmol} / \mathrm{L})$ or docetaxel $(100 \mathrm{ng} / \mathrm{mL})$ or a combination of both for $48 \mathrm{~h}$. The cell apoptosis rate was analyzed using a flow cytometer. Data are expressed as mean \pm SD (n=3 per group), ${ }^{*} p<0.05$ vs Vector; ${ }^{*} p<0.05$ vs Vector+SB; ${ }^{*} p<0.05$ vs Vector+DTX; ${ }^{\Delta} p<0.05$ vs OE-Glil; ${ }^{\diamond} p<0.05$ vs Vector+SB+DTX. 

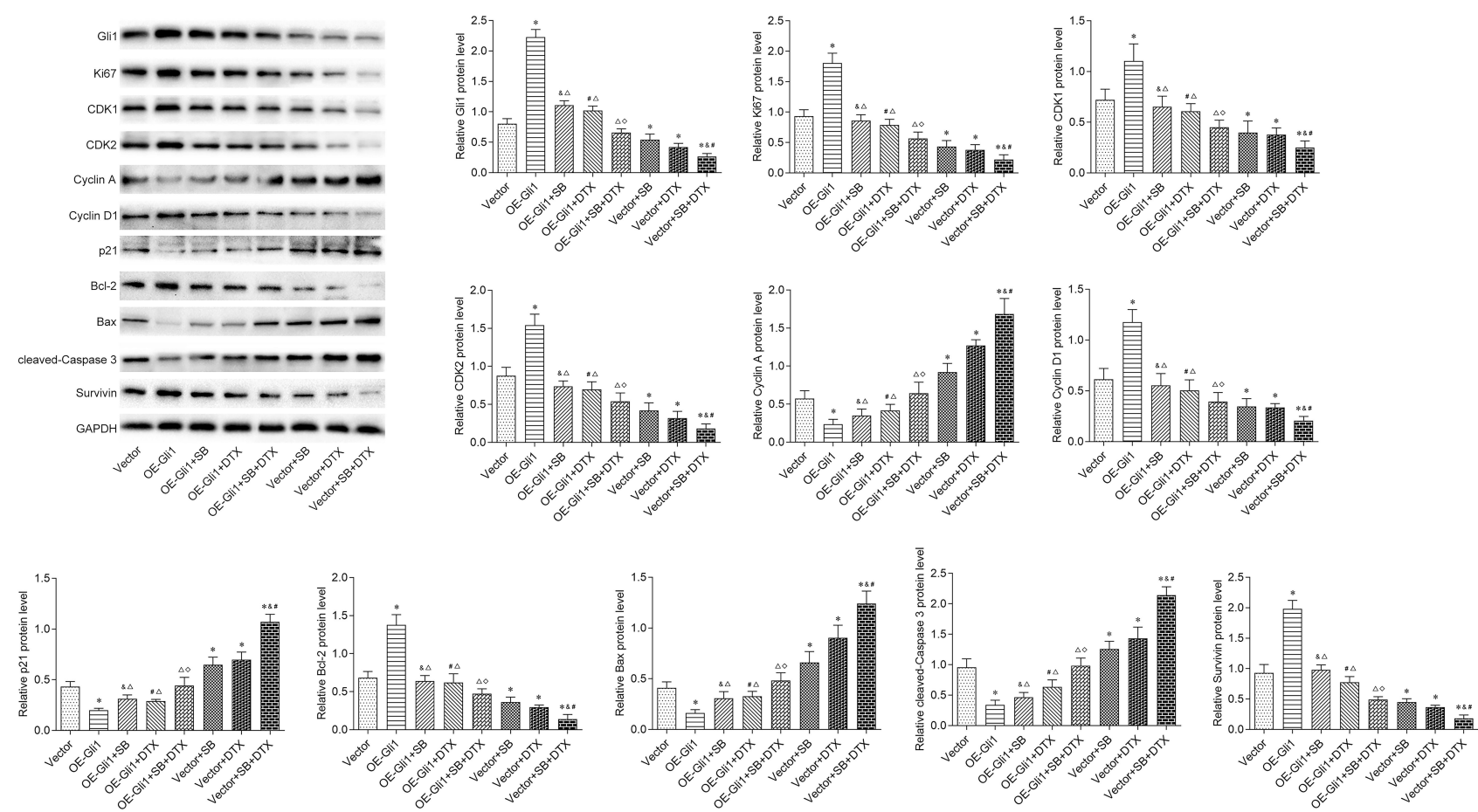

Figure $6 \mathrm{Glil}$ overexpression reverses the additive effect of sodium butyrate with docetaxel combined treatment on its downstream proteins related to proliferation, cell cycle and apoptosis in A549 cells. After successful transfection of Glil, cells were treated with sodium butyrate ( $10 \mathrm{mmol} / \mathrm{L})$ or docetaxel (I00 ng/mL) or a combination of both for 48 h. The protein expressions of Ki-67, CDKI, CDK2, Cyclin A, Cyclin DI, p2I, Bcl-2, Bax, cleaved-Caspase 3 and Survivin were determined by Western blot. Data are expressed as mean \pm SD ( $n=3$ per group), ${ }^{*} p<0.05$ vs Vector; ${ }^{\&} p<0.05$ vs Vector+SB; ${ }^{\#} p<0.05$ vs Vector+DTX; ${ }^{\Delta} p<0.05$ vs OE-Glil; ${ }^{\diamond} p<0.05$ vs Vector+SB+DTX.

generated by the combined treatment was partially abrogated by Gli1 overexpression (Figure 7B-D). On the other hand, the TUNEL analysis of shaped tumor specimens showed that the combined treatment markedly promoted tumor apoptosis, which was perceptibly abrogated by the overexpression of Gli1 (Figure 7E). Additionally, Western blot was conducted to evaluate the levels of Gli1 downstream proteins in shaped tumor tissues involving in proliferation, cell cycle and apoptosis, and the obtained results showed that the combined treatment significantly reduced the protein expressions of Ki-67, CDK1, CDK2, Cyclin D1, Bcl-2 and Survivin, and enhanced the protein expressions of Cyclin A, p21, Bax and cleaved-Caspase 3. Of noted, the expression effect of the above-mentioned proteins generated by the combined treatment was perceptibly reversed under Gli1 overexpression (Figure 8), which was consistent with the in vitro results as stated before (Figure 6). Altogether, these data suggest that the combined treatment inhibits in vivo A549 cell xenograft tumor growth via suppressing Glil expression and regulating the expression of its downstream proteins involving in proliferation, cell cycle, and apoptosis.

\section{Discussion}

Accumulating evidences have confirmed the anti-tumor activity of sodium butyrate. Salimi et al showed that sodium butyrate promotes apoptosis and imposes cell cycle arrest in breast cancer through reactive oxygen species formation and mitochondrial impairment. ${ }^{7}$ Sodium butyrate has also exhibited anti-cancer activity in gastric cancer via inducing apoptosis. ${ }^{8}$ Wang and colleagues revealed that sodium butyrate inhibits migration and induces AMPK-mTOR pathway-dependent autophagy and ROS-mediated apoptosis in bladder cancer cells via the miR-139-5p/Bmi-1 axis, suggesting that sodium butyrate may be a novel chemotherapeutic agent in the clinical treatment of bladder cancer. ${ }^{9}$ In addition, several studies have reported that sodium butyrate enhances anti-tumor effect of chemotherapy and resensitizes chemo-resistant tumor cells. ${ }^{20,21}$ For example, Koprinarova et al showed that sodium butyrate sensitizes HeLa cells towards cisplatin through abrogating the cisplatin imposed cell cycle arrest. ${ }^{20}$ A recent study also confirmed that sodium butyrate not only suppresses the proliferation, but also enhances the cytotoxic effect of cisplatin in ovarian cancer. ${ }^{21}$ Most recently, Xiao and coworkers studied the lung adenocarcinoma A549 cells and 


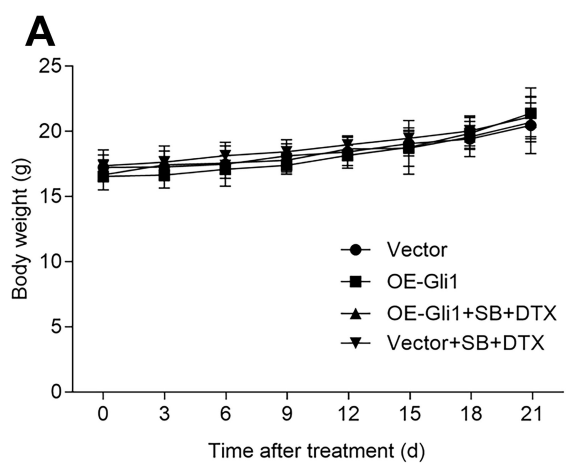

B

C
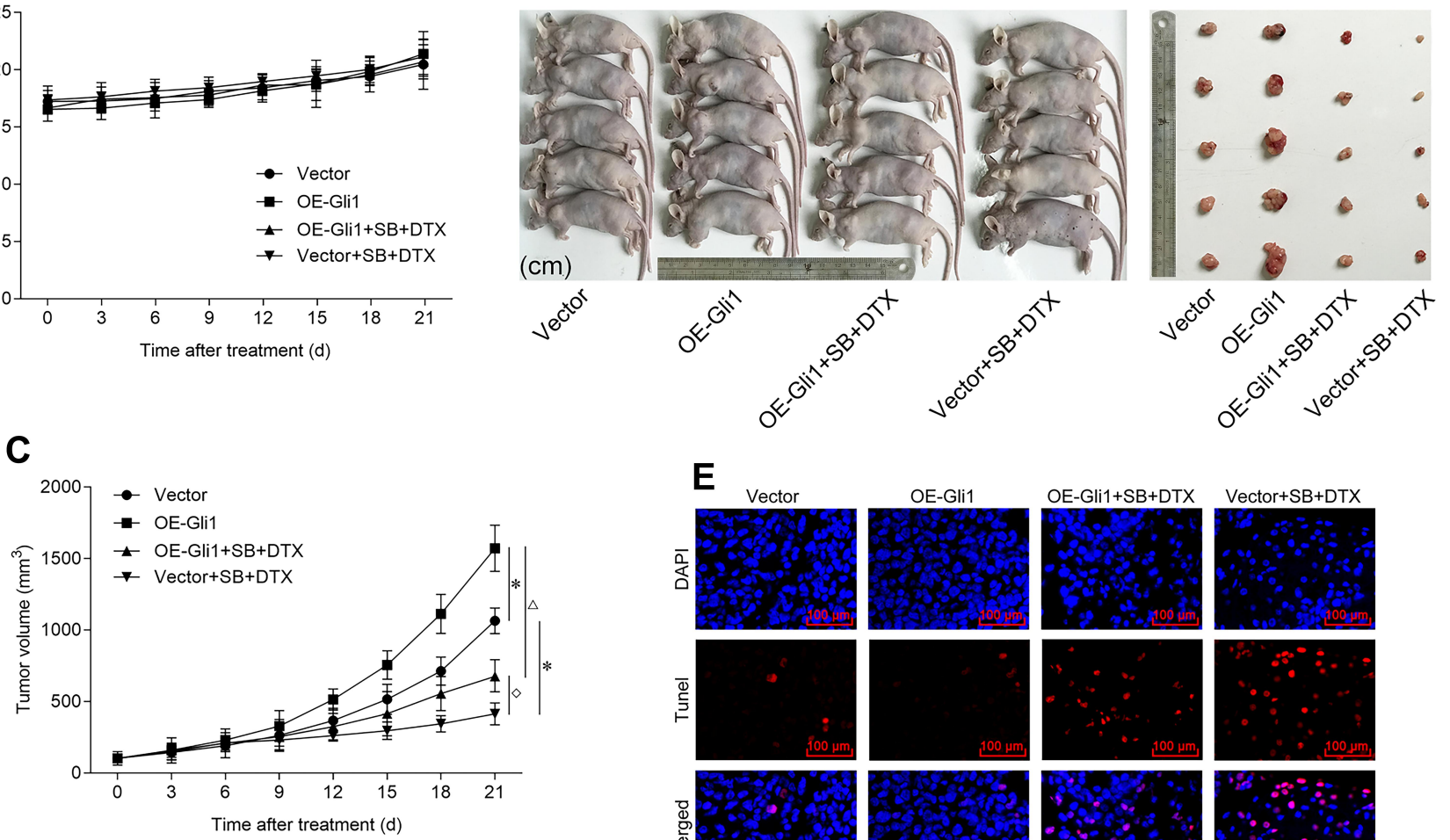

OE-Gli1

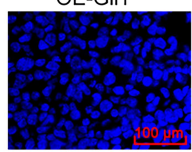

OE-Gli1+SB+DTX
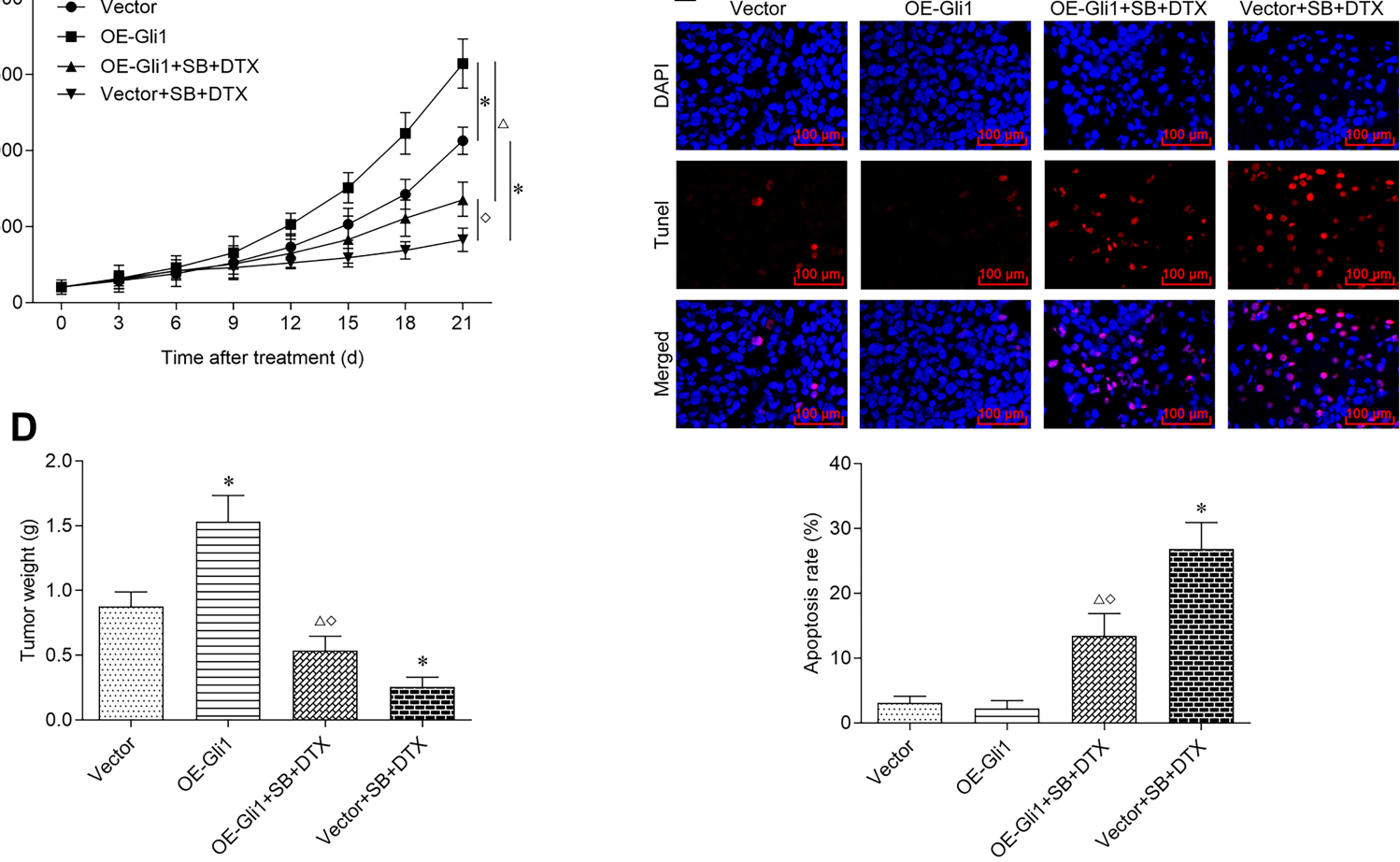

Figure 7 Combined treatment of sodium butyrate with docetaxel additively inhibits in vivo A549 cell xenograft tumor growth via suppressing Glil expression. Nude mice bearing A549 cells (with Glil overexpression or negative control vectors) were intraperitoneally injected with sodium butyrate (500 mg/kg, once a day) and docetaxel ( $8 \mathrm{mg} /$ $\mathrm{kg}$, once in three days) for $2 \mathrm{I}$ days. (A) The body weight changes of nude mice during the treatment period were recorded. (B) The shaped tumors after the final treatment were photographed. (C) The development of tumor size during the treatment period was recorded. (D) The tumor weight after the final treatment was measured. (E) The shaped tumors after the final treatment were obtained for TUNEL staining (scale bar $100 \mu \mathrm{m}$ ). The TUNEL positive cells were quantified by using Image-Pro Plus 5.0 software. Data are expressed as mean \pm SD ( $n=5$ per group), ${ }^{*} p<0.05$ vs Vector; ${ }^{\Delta} p<0.05$ vs OE-Glil; ${ }^{\diamond} p<0.05$ vs Vector+SB+DTX.

revealed that sodium butyrate-dependent alleviation of tumorigenesis of TRAF6. ${ }^{12}$ Despite these results, the overall treating efficacy is sub-optimal, and a combined therapy of sodium butyrate with other chemotherapeutic drugs may generate an additive effect that could further improve the efficacy. In the present study, we aimed to investigate the combined treating efficacy of sodium butyrate with docetaxel on proliferation and apoptosis of lung adenocarcinoma A549 cells and further explore the underlying mechanisms. Consistent with previous studies regarding the anti-cancer activity of sodium butyrate, we observed the potential anti-tumor activity of sodium butyrate in lung adenocarcinoma A549 cells through inhibiting proliferation, inducing cell cycle arrest, and promoting apoptosis, whereas the additive anti-tumor effect of sodium butyrate with docetaxel was indicated by in vitro and in vivo study. In addition, no obvious adverse event was found with combined treatment, which should be further verified prior to clinical implementation. 

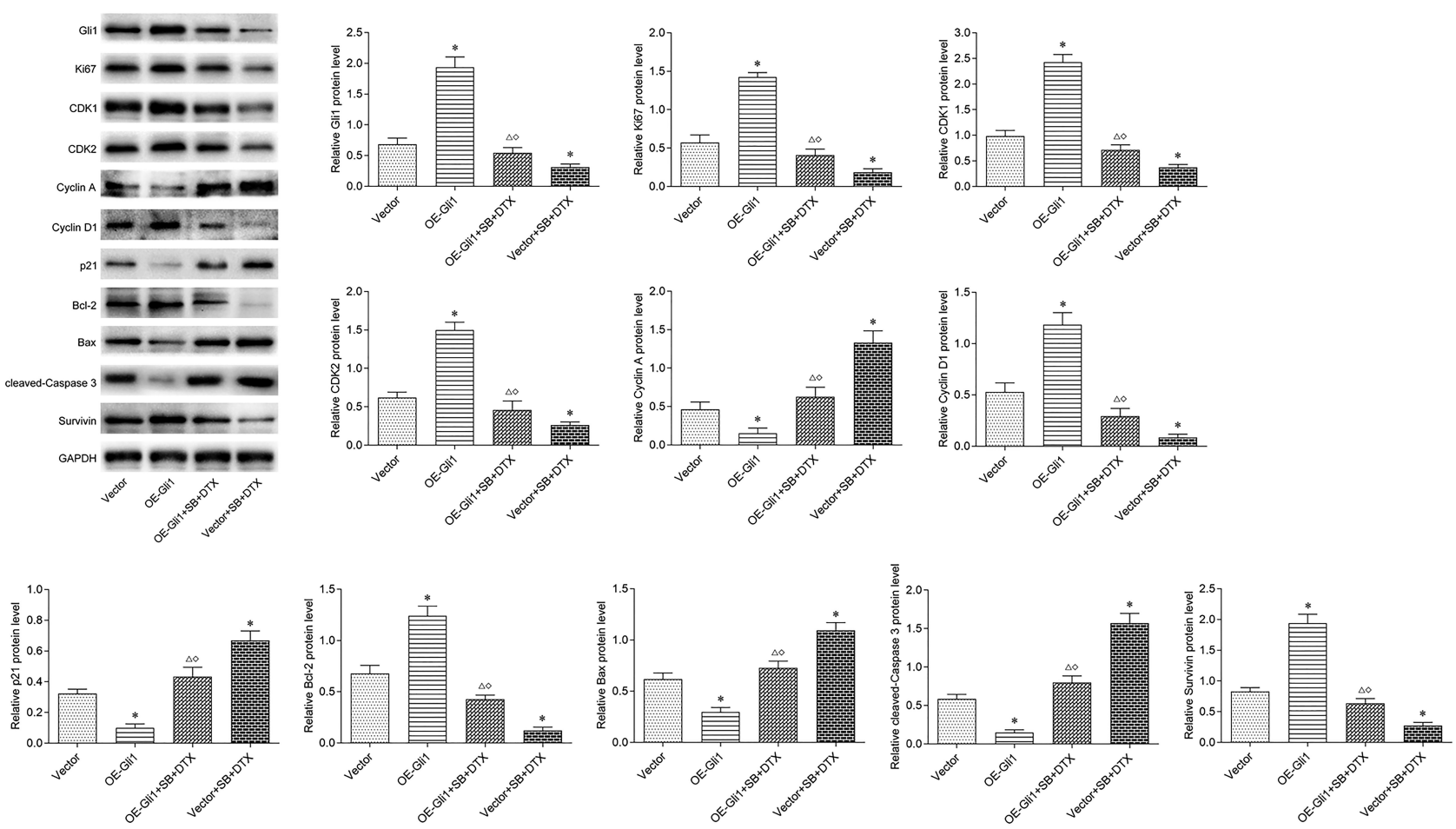

Figure $8 \mathrm{Glil}$ overexpression reverses the additive effect of sodium butyrate with docetaxel combined treatment on its downstream proteins related to proliferation, cell cycle, and apoptosis in in vivo A549 cell xenograft tumor. Nude mice bearing A549 cells (with Glil overexpression or negative control vectors) were intraperitoneally injected with sodium butyrate $(500 \mathrm{mg} / \mathrm{kg}$, once a day) and docetaxel $(8 \mathrm{mg} / \mathrm{kg}$, once in three days) for $2 \mathrm{I}$ days. The fresh shaped tumors after the final treatment were obtained and the protein expressions of Ki-67, CDKI, CDK2, Cyclin A, Cyclin DI, p2I, Bcl-2, Bax, cleaved-Caspase 3 and Survivin were determined by Western blot. Data are expressed as mean \pm SD ( $n=5$ per group), ${ }^{*} p<0.05$ vs Vector; ${ }^{\Delta} p<0.05$ vs OE-Glil; ${ }^{\diamond} p<0.05$ vs Vector+SB+DTX.

Zinc finger protein Gli1 is a major transcription factor of Gli family acting as a transcriptional activator. ${ }^{22}$ As the effectors of Hedgehog (Hh) signaling, Gli1 is overexpressed in numerous malignant tumors, and several mechanisms activating Gli1 expression have been confirmed. For example, excessive production of Hh ligand results in enhanced autocrine and paracrine signals; ${ }^{23,24}$ Furthermore, upstream gene mutations of the Hh pathway (Smo and Ptch) activate downstream Gli1; ${ }^{25,26}$ Mutation or isomers of Gli1 also result in Gli1 activation; ${ }^{27-29}$ Lastly, various non-classical $\mathrm{Hh}$ pathways upregulate Gli1 expression. ${ }^{30,31}$ Nevertheless, all activators of $\mathrm{Hh}$ signaling pathway ultimately act on the effector Gli1 to activate Hh pathway and promote cancer development. Po et al confirmed that in 1007 lung adenocarcinomas, percentage of Gli1 high expression was as high as $76 \%{ }^{15}$ Along these lines, we up-regulated Gli1 expression in lung adenocarcinoma A549 cells to explore the effect of Gli1 on the biological behavior of lung adenocarcinoma. Our results confirmed that overexpression of Gli1 could significantly promote the growth of lung adenocarcinoma A549 cells in vitro and in vivo. Consistent with our findings, recent investigations also reported that abnormally high expression of Glil is noted in glioblastoma, and antagonizing Gli1 could inhibit growth and reduce the chemoresistance and stemness of glioblastoma cells. ${ }^{32-34}$

Considering that the transcriptional activity of Gli1 is regulated by histone deacetylase (HDAC) ${ }^{14}$ sodium butyrate as a HDAC inhibitor may down-regulate Gli1 expression to suppress tumorigenesis and progression. Therefore, we explored the effects of sodium butyrate and its combination with docetaxel on Gli1 expression in lung adenocarcinoma A549 cells. We observed that sodium butyrate significantly inhibited the mRNA and protein expression of Gli1, which were more remarkable in combination with docetaxel. These results indicated that the down-regulation of Gli1 expression may be one of the underlying mechanisms of the inhibitory effect and the chemosensitization effect of sodium butyrate on lung adenocarcinoma A549 cells. Notably, with Gli1 overexpression, the effects of sodium butyrate and its combined treatment with docetaxel on the proliferation and apoptosis of A549 cells were palpably reversed, which further validated the crucial role of Glil in the underlying mechanism. We hypothesized 
that the inhibitory effect of HDAC inhibitor sodium butyrate on Gli1 expression and tumor growth may result from its inhibition of deacetylase to suppress non-classical activation of the Hh signaling pathway based on Glil regulation. ${ }^{14}$ However, the specific regulatory mechanism of HDAC inhibitor on Gli1 is not fully understood, and the interaction between deacetylase-regulated acetylation and Hh/Gli1 signaling pathway in lung adenocarcinoma still need further investigation.

Studies suggested that Gli1 participated in tumorigenesis through modulating the expression of key genes involving in multiple oncogenic signaling pathways. For example, Gli1 has been reported to aggravate proliferation through regulating the expressions of $\mathrm{Ki} 67$, CDK1, CDK2, Cyclin A, Cyclin D1, P21, etc.; whereas suppress apoptosis through regulating the expressions of Bcl-2, Bax, Caspase-3, Survivin, etc. ${ }^{35-38}$ Considering that Gli1 may regulate multiple oncogenic signaling pathways to drive tumorigenesis and progression, we observed the relationship between Gli1 and its reported downstream proteins involving in proliferation, cell cycle and apoptosis. Our results indicated that Gli1 overexpression significantly increased the protein expressions of Ki-67, CDK1, CDK2, Cyclin D1, Bcl-2 and Survivin, and decreased the protein levels of Cyclin A, p21, Bax and cleaved-Caspase 3. More importantly, the treatment efficacy of the above-mentioned proteins generated by the combined treatment of sodium butyrate with docetaxel was perceptibly reversed under Glil overexpression. These findings suggest that the combined treatment of sodium butyrate with docetaxel may exhibit antitumor activity in A549 cells through targeting Gli1mediated downstream signal molecules.

\section{Conclusion}

In conclusion, this study demonstrates that sodium butyrate combined with docetaxel additively inhibits proliferation and promotes apoptosis of A549 cells via suppressing Gli1 expression in vitro and in vivo. Targeting Gli1 by the combined therapy may provide new insights into the therapeutic management of patients with lung adenocarcinoma.

\section{Funding}

This work was supported by the foundation of the National Natural Science Foundation of China (No. 81360396), the International Communication of Guangxi Medical University Graduate Education, the Science and Technology Infrastructure Project of Guangxi (No.15-
235-05) and the Innovation Project of Guangxi Graduate Education (No. YCSW2017108).

\section{Disclosure}

The authors report no conflicts of interest in this work.

\section{References}

1. Siegel RL, Miller KD, Jemal A. Cancer statistics, 2019. CA Cancer J Clin. 2019;69(1):7-34. doi:10.3322/caac.21551

2. Li J, Li YJ, Wang B, Ma Y, Chen P. Id-1 promotes migration and invasion of non-small cell lung cancer cells through activating NF-kappaB signaling pathway. J Biomed Sci. 2017;24(1):95. doi:10.1186/s12929-017-0400-6

3. Kadara H, Kabbout M, Wistuba II. Pulmonary adenocarcinoma: a renewed entity in 2011. Respirology. 2012;17(1):50-65. doi:10.1111/j.1440-1843.2011.02095.x

4. Blandin Knight S, Crosbie PA, Balata H, Chudziak J, Hussell T, Dive C. Progress and prospects of early detection in lung cancer. Open Biol. 2017;7(9):170070. doi:10.1098/rsob.170070

5. Visconti R, Morra F, Guggino G, Celetti A. The between now and then of lung cancer chemotherapy and immunotherapy. Int J Mol Sci. 2017;18(7):1374. doi:10.3390/ijms18071374

6. Tsilimigras DI, Ntanasis-Stathopoulos I, Moris D, Spartalis E, Pawlik TM. Histone deacetylase inhibitors in hepatocellular carcinoma: a therapeutic perspective. Surg Oncol. 2018;27(4):611-618. doi:10.1016/j.suronc.2018.07.015

7. Salimi V, Shahsavari Z, Safizadeh B, Hosseini A, Khademian N, Tavakoli-Yaraki M. Sodium butyrate promotes apoptosis in breast cancer cells through reactive oxygen species (ROS) formation and mitochondrial impairment. Lipids Health Dis. 2017;16(1):208. doi:10.1186/s12944-017-0593-4

8. Calcagno DQ, Wisnieski F, Mota E, et al. Role of histone acetylation in gastric cancer: implications of dietetic compounds and clinical perspectives. Epigenomics. 2019;11(3):349-362. doi:10.2217/epi-20180081

9. Wang FF, Wu HS, Fan MJ, et al. Sodium butyrate inhibits migration and induces AMPK-mTOR pathway-dependent autophagy and ROS-mediated apoptosis via the miR-139-5p/Bmi-1 axis in human bladder cancer cells. FASEB J. 2020;34(3):4266-4282. doi:10.1096/ fj.201902626R

10. Kazemi Sefat NA, Mohammadi MM, Hadjati J, Talebi S, Ajami M, Daneshvar H. Sodium butyrate as a histone deacetylase inhibitor affects toll-like receptor 4 expression in colorectal cancer cell lines. Immunol Invest. 2019;48(7):759-769. doi:10.1080/08820139.2019.1595643

11. Jia XY, Zheng YS, Guo YZ, Chen K. Sodium butyrate and panobinostat induce apoptosis of chronic myeloid leukemia cells via multiple pathways. Mol Genet Genomic Med. 2019;7(5):e613. doi:10.1002/ $\operatorname{mgg} 3.613$

12. Xiao XQ, Xu YX, Chen HY. Sodium butyrate-activated TRAF6-TXNIP pathway affects A549 cells proliferation and migration. Cancer Med. 2019;9(10):3477-3488. doi:10.1002/ cam4.2564

13. Kinzler KW, Vogelstein B. The GLI gene encodes a nuclear protein which binds specific sequences in the human genome. Mol Cell Biol. 1990;10(2):634-642. doi:10.1128/MCB.10.2.634

14. Canettieri G, Di Marcotullio L, Greco A, et al. Histone deacetylase and Cullin3-REN(KCTD11) ubiquitin ligase interplay regulates hedgehog signalling through Gli acetylation. Nat Cell Biol. 2010;12 (2):132-142. doi:10.1038/ncb2013

15. Po A, Silvano M, Miele E, et al. Noncanonical GLI1 signaling promotes stemness features and in vivo growth in lung adenocarcinoma. Oncogene. 2017;36(32):4641-4652. doi:10.1038/ onc.2017.91 
16. Yang Q, Shen SS, Zhou S, et al. STAT3 activation and aberrant ligand-dependent sonic hedgehog signaling in human pulmonary adenocarcinoma. Exp Mol Pathol. 2012;93(2):227-236. doi:10.1016/j.yexmp.2012.04.009

17. Li X, Li F, Wang FF, Li JF, Lin CZ, Du JX. Resveratrol inhibits the proliferation of A549 cells by inhibiting the expression of COX-2. Onco Targets Ther. 2018;11:2981-2989. doi:10.2147/OTT.S157613

18. Feng SQ, Wang GJ, Zhang JW, et al. Combined treatment with apatinib and docetaxel in A549 xenograft mice and its cellular pharmacokinetic basis. Acta Pharmacol Sin. 2018;39(10):1670-1680. doi:10.1038/aps.2018.16

19. Jang B, Yang IH, Cho NP, et al. Down-regulation and nuclear localization of survivin by sodium butyrate induces caspase-dependent apoptosis in human oral mucoepidermoid carcinoma. Oral Oncol. 2019;88:160-167. doi:10.1016/j. oraloncology.2018.11.032

20. Koprinarova M, Markovska P, Iliev I, Anachkova B, Russev G. Sodium butyrate enhances the cytotoxic effect of cisplatin by abrogating the cisplatin imposed cell cycle arrest. BMC Mol Biol. 2010;11 (1):49. doi:10.1186/1471-2199-11-49

21. Mrkvicova A, Chmelarova M, Peterova E, et al. The effect of sodium butyrate and cisplatin on expression of EMT markers. PLoS One. 2019;14(1):e0210889. doi:10.1371/journal.pone.0210889

22. Didiasova M, Schaefer L, Wygrecka M. Targeting GLI transcription factors in cancer. Molecules. 2018;23(5):1003. doi:10.3390/ molecules23051003

23. Yoo YA, Kang MH, Lee HJ, et al. Sonic hedgehog pathway promotes metastasis and lymphangiogenesis via activation of Akt, EMT, and MMP-9 pathway in gastric cancer. Cancer Res. 2011;71 (22):7061-7070. doi:10.1158/0008-5472.CAN-11-1338

24. Liu ZQ, Xu JD, He J, et al. A critical role of autocrine sonic hedgehog signaling in human CD138+ myeloma cell survival and drug resistance. Blood. 2014;124(13):2061-2071. doi:10.1182/blood2014-03-557298

25. Geyer N, Ridzewski R, Bauer J, et al. Different response of Ptch mutant and Ptch wildtype rhabdomyosarcoma toward SMO and PI3K inhibitors. Front Oncol. 2018;8:396. doi:10.3389/fonc.2018.00396

26. Palle K, Mani C, Tripathi K, Athar M. Aberrant GLI1 activation in DNA damage response, carcinogenesis and chemoresistance. Cancers (Basel). 2015;7(4):2330-2351. doi:10.3390/cancers7040894

27. Lee JH, Song SY, Kim MS, Yoo NJ, Lee SH. Intratumoral heterogeneity of frameshift mutations of GLI1 encoding a hedgehog signaling protein in colorectal cancers. Pathol Oncol Res. 2018;24 (3):477-481. doi:10.1007/s12253-017-0272-9
28. Miettinen M, Felisiak-Golabek A, Contreras AL, et al. New fusion sarcomas histopathology and clinical significance of selected entities. Hum Pathol. 2019;86:57-65. doi:10.1016/j.humpath.2018.12.006

29. Lo HW, Zhu H, Cao XY, Aldrich A, Ali-Osman F. A novel splice variant of GLI1 that promotes glioblastoma cell migration and invasion. Cancer Res. 2009;69(17):6790-6798. doi:10.1158/00085472.CAN-09-0886

30. Dennler S, Andre J, Alexaki I, et al. Induction of sonic hedgehog mediators by transforming growth factor-beta: smad3-dependent activation of Gli2 and Gli1 expression in vitro and in vivo. Cancer Res. 2007;67(14):6981-6986. doi:10.1158/0008-5472.CAN-07-0491

31. Javelaud D, Alexaki VI, Dennler S, Mohammad KS, Guise TA, Mauviel A. TGF-beta/SMAD/GLI2 signaling axis in cancer progression and metastasis. Cancer Res. 2011;71(17):5606-5610. doi:10.1158/0008-5472.CAN-11-1194

32. Bar EE, Chaudhry A, Lin A, et al. Cyclopamine-mediated hedgehog pathway inhibition depletes stem-like cancer cells in glioblastoma. Stem Cells. 2007;25(10):2524-2533. doi:10.1634/stemcells.20070166

33. Melamed JR, Ioele SA, Hannum AJ, Ullman VM, Day ES. Polyethylenimine-spherical nucleic acid nanoparticles against Gli1 reduce the chemoresistance and stemness of glioblastoma cells. Mol Pharm. 2018;15(11):5135-5145. doi:10.1021/acs.molpharmaceut. $8 \mathrm{~b} 00707$

34. Melamed JR, Morgan JT, Ioele SA, Gleghorn JP, Sims-Mourtada J, Day ES. Investigating the role of Hedgehog/GLI1 signaling in glioblastoma cell response to temozolomide. Oncotarget. 2018;9 (43):27000-27015. doi:10.18632/oncotarget.25467

35. Chen XJ, Horiuchi A, Kikuchi N, et al. Hedgehog signal pathway is activated in ovarian carcinomas, correlating with cell proliferation: it's inhibition leads to growth suppression and apoptosis. Cancer Sci. 2007;98(1):68-76. doi:10.1111/j.1349-7006.2006.00353.x

36. Mazumdar T, Devecchio J, Agyeman A, Shi T, Houghton JA. Blocking hedgehog survival signaling at the level of the GLI genes induces DNA damage and extensive cell death in human colon carcinoma cells. Cancer Res. 2011;71(17):5904-5914. doi:10.1158/ 0008-5472.CAN-10-4173

37. Shi T, Mazumdar T, Devecchio J, et al. cDNA microarray gene expression profiling of hedgehog signaling pathway inhibition in human colon cancer cells. PLoS One. 2010;5(10):e13054. doi:10.1371/journal.pone.0013054

38. Wang K, Pan L, Che XM, Cui DM, Li C. Gli1 inhibition induces cell-cycle arrest and enhanced apoptosis in brain glioma cell lines. J Neurooncol. 2010;98(3):319-327. doi:10.1007/s11060-009-0082-3
OncoTargets and Therapy

\section{Publish your work in this journal}

OncoTargets and Therapy is an international, peer-reviewed, open access journal focusing on the pathological basis of all cancers, potential targets for therapy and treatment protocols employed to improve the management of cancer patients. The journal also focuses on the impact of management programs and new therapeutic

Submit your manuscript here: https://www.dovepress.com/oncotargets-and-therapy-journa agents and protocols on patient perspectives such as quality of life, adherence and satisfaction. The manuscript management system is completely online and includes a very quick and fair peer-review system, which is all easy to use. Visit http://www.dovepress.com/ testimonials.php to read real quotes from published authors. 